\title{
Identification of Dominant Arbuscular Mycorrhizal Fungi in Different Rice Ecosystems
}

\author{
Wendy F. Xavier Martins ${ }^{1} \cdot$ B. F. Rodrigues ${ }^{1}$
}

Received: 26 October 2018/Accepted: 27 April 2019/Published online: 9 May 2019

(C) The Author(s) 2019

\begin{abstract}
Rice is a staple food in Goa. It is cultivated in three different ecosystems, viz, lowland (khazan), midland (ker) and upland (morod). The present investigation was carried out for two consecutive years, i.e., 2015 and 2016 to study the diversity of arbuscular mycorrhiza (AM) and identify the dominant species in the three different rice ecosystems of Goa. The native dominant AM species identified from the study can be further employed for developing AM inocula. The study revealed 17 AM fungal species recorded from the three ecosystems and belonged to six genera, viz., Acaulospora (9), Rhizoglomus (1), Entrophospora (1), Claroideoglomus (2), Funneliformis (1) and Gigaspora (3). There was dominance of different genera in different ecosystems. The genus Acaulospora was abundant in lowlands, genus Gigaspora in midlands and the genus Claroideoglomus in upland fields. This study suggests the possibility of using inocula of the dominant AM species in the respective ecosystems for increased plant growth and yield.
\end{abstract}

Keywords AM fungi $\cdot$ Diversity $\cdot$ Dominance $\cdot$ Inocula

\section{Introduction}

One of the important crops grown in many tropical countries of the world is rice (Oryza sativa L.). It is grown in different ecosystems defined on the basis of hydrology, roughly classified as irrigated, rainfed lowland, upland and flood prone. Approximately, half of the world rice area is irrigated and of the remainder is distributed among rainfed lowland (25\%), uplands (13\%) and flood prone (9\%) $[11,12,15]$. The degree of flooding is determined by a number of variables such as rainfall pattern and intensity, topography, soil properties and drainage system [16].

Rice is the staple food of Goa. The crop is cultivated in three different topographical situations, i.e., upland (morod), midland (ker) and lowland (khazans) mainly as wet season (kharif) crop from June to October. Rice cultivation in

Wendy F. Xavier Martins wendyfxavier@gmail.com

1 Department of Botany, Goa University, Taleigao, Goa 403 206, India uplands is $16.4 \%$ of the total rice area in the state. The growing period is 115-120 days. Fields are prepared by plowing early in the season followed by leveling so that the field is ready for sowing before the regular onset of monsoon. Pre-germinated seeds are broadcasted, or plantlets are transplanted by planting uniformly in lines spaced by $20 \mathrm{~cm}$. Broadcasting and transplanting are carried out with a thin film of water. Rice crop cultivated in midland is $32 \%$ of the total rice area in the state. The crop grown in this ecosystem has relatively longer growing period (130-135 days). Seedlings are raised in wet or dry nurseries after germination. The seedlings are ready for transplanting after 21-24 days. Three to four seedlings are planted per hill at a distance of $20 \times 10 \mathrm{~cm}$. Seedlings are transplanted in fields that are plowed and leveled at the first shower. Rice cultivation in the lowland occupies an area of $32 \%$ of the rice area in the state, with varieties having growth duration of 105-115 days. Fields are plowed in the summer. Seeds are either broadcasted or transplanted by raising a nursery. However, in the lowland, it is essential to sow at regular onset of monsoon after ensuring flushing of salts from the fields [24]. 
Mycorrhiza is a mutualistic association between fungi and plant roots. The fungus enters into the cortex of the roots to obtain carbon from the host plant, and in return it assists the plants with the uptake of phosphorus $(\mathrm{P})$ and other nutrients from the soil [2]. Besides, other functions attributed to AM fungi include production of plant growth hormones, protection of host from pathogens and salinity tolerance $[4,5]$.

Rice plants readily form AM association in upland [23] and midland [48] condition, but under submerged condition colonization is rare due to the anoxic environment [13]. However, Barea [3] concluded that AM fungi are obligate aerobes in nature, but can survive in waterlogged condition. Lower rate of AM fungal colonization was observed in rice roots in wet as compared to dry condition, and the rate of AM fungal colonization decreased during rice growth as observed by Solaiman and Hirata [44]. The increasing awareness of occurrence of AM fungi in wetland ecosystem $[14,26,29,51,53]$ leads to the conclusion that soil conditions determine the mycorrhizal status of the host. Miller [27] and Wang et al. [51] found a decrease in the degree of AM fungal colonization with flooding along wetland gradient. But the presence of AM fungi in wetland ecosystem is closely related to the well-developed aerenchyma in wetland plant roots $[19,26,51]$ that allows AM fungi to obtain atmospheric oxygen [32].

In the recent past, attempts have been made to obtain suitable formulation for AM fungal inocula and appropriate ways for their application in the field [8]. The development of inocula based on AM fungi has to take into account the indigenous AM fungal population. Hence, the aim of the present work was to study the distribution of native AM fungal community in different ecologies in order to formulate AM inocula types for different ecosystems.

\section{Materials and Methods}

\section{Collection Sites}

Rhizosphere soil samples (Table 1) from three rice varieties, viz, Jyoti, Khonchri and Jaya were collected from lowland, midland and upland during the vegetative, flowering and harvesting stages for two consecutive years, viz, 2015 and 2016. In all, 81 rhizosphere soil samples were collected and brought to the laboratory for further processing.

\section{Collection of Samples}

Three healthy plants were selected from three different positions in the field. Soil and root samples were taken from a depth of $0-25 \mathrm{~cm}$, in polyethylene bags and brought to the laboratory. The roots were separated from adhering soil by washing gently under tap water and were used for estimation of AM colonization. The rhizosphere soil of the three healthy plants from each site at each growth stage was pooled to form composite sample. The composite soil samples were then divided into three parts, for (i) isolation, enumeration and identification of AM spores, (ii) preparing trap cultures and (iii) soil analysis.

\section{Soil Analysis}

Soil $\mathrm{pH}$ was measured in 1:1 water solution suspension using a pH meter (LI 120 Elico, India). Electrical conductivity (EC) was measured using conductivity meter (CM 180 Elico, India). Walkley and Black [52] rapid titration method was used to estimate organic carbon content. Nitrogen was assessed by micro-Kjeldahl method [17]. Available $\mathrm{P}$ was estimated using Bray and Kurtz method [6]. Potassium (K) was estimated by ammonium acetate method [9]. Zinc, iron, manganese and copper were quantified by DTPA-CaCl $\mathrm{Cl}_{2}$-TEA method from Lindsay and Norvell [20] using atomic absorption spectrophotometer

Table 1 Rice varieties and geographical location of the study sites

\begin{tabular}{|c|c|c|c|c|c|}
\hline \multirow[t]{2}{*}{ Ecosystem } & \multirow[t]{2}{*}{ Site } & \multirow[t]{2}{*}{ Rice variety } & \multicolumn{3}{|c|}{ Geographical coordinates } \\
\hline & & & Latitude & Longitude & $\begin{array}{l}\text { Altitude (m } \\
\text { above msl) }\end{array}$ \\
\hline \multirow[t]{2}{*}{ Lowland (Khazan) } & Sikeri & Jyoti, Khonchri & $15^{\circ} 35^{\prime} 18^{\prime \prime} \mathrm{N}$ & $73^{\circ} 53^{\prime} 20^{\prime \prime} \mathrm{E}$ & 7 \\
\hline & Tuem & Jaya & $15^{\circ} 30^{\prime} 22^{\prime \prime} \mathrm{N}$ & $73^{\circ} 48^{\prime} 12^{\prime \prime} \mathrm{E}$ & 3 \\
\hline \multirow[t]{2}{*}{ Midland (Ker) } & Saligao & Jyoti Khonchri & $15^{\circ} 33^{\prime} 07^{\prime \prime} \mathrm{N}$ & $73^{\circ} 47^{\prime} 01^{\prime \prime} \mathrm{E}$ & 29 \\
\hline & Velim & Jaya & $15^{\circ} 09^{\prime} 39^{\prime \prime} \mathrm{N}$ & $73^{\circ} 58^{\prime} 45^{\prime \prime} \mathrm{E}$ & 21 \\
\hline \multirow[t]{2}{*}{ Upland (Morod) } & Morpilla & Jyoti & $15^{\circ} 06^{\prime} 53^{\prime \prime} \mathrm{N}$ & $73^{\circ} 59^{\prime} 54^{\prime \prime} \mathrm{E}$ & 378 \\
\hline & Quitolla & Khonchri, Jaya & $15^{\circ} 07^{\prime} 58^{\prime \prime} \mathrm{N}$ & $73^{\circ} 57^{\prime} 36^{\prime \prime} \mathrm{E}$ & 204 \\
\hline
\end{tabular}

$m s l$ mean sea level 
(AAS-EC Element AS AAS4139). Chemical analyses of the soil samples were carried out at Soil Science Laboratory, ICAR-CCARI, Old Goa.

\section{Estimation of AM Fungal Root Colonization}

The root samples of three different rice varieties were collected at three different growth stages from three different ecosystems. Roots were washed thoroughly in tap water, cut into $1-\mathrm{cm}$ fragments and stained with Trypan blue following the method described by Phillip and Hayman [32]. Fifty stained roots were examined for AM fungal structures. Percentage of root colonization was determined by root slide method [34].

\section{Isolation and Identification of AM Spores}

Spores were isolated from rhizosphere soil samples using wet sieving and decanting method [7]. Intact and crushed spores were mounted in polyvinyl lacto-glycerol and examined under an Olympus research compound microscope $(100 \times-1000 \times)$. Morphological identification of the spores was carried out by using bibliographies [1,36], and the culture database established by INVAM.

\section{Diversity Studies and Statistical Analysis}

Mycorrhizal Diversity for each ecosystem was studied separately by calculating:
A. Frequency
of
occurrence
$(\%)=$
$\frac{\text { Number of soil samples containing spores of particular AM species }}{\text { Total number of soil samples screened }} \times 100$
[4]
B. Relative abundance
$\frac{\text { Number of spores of particular } A M \text { species }}{\text { Total spore number of all the AM Species }} \times 100$ [4]
$(\%)=$
C. Species richness (SR) is the number of AM fungal species recovered from each site per sample collection
D. Simpson's Index of Diversity: $1-D$ [40]
$D=1-\Sigma\left(P_{i}\right)^{2}$
$P_{i}=n_{i} / N$

$n_{\mathrm{i}}$ - the relative abundance of the species calculated as the proportion of individuals of a given species to the total number of individuals in a community $N$.

E. Shannon diversity index $(H)$ by Shannon and Wiener [42] is commonly used to characterize species diversity in a community, accounting for both abundance and evenness of the species present.

$H=-\Sigma\left(P_{i} \operatorname{In}\left(P_{i}\right)\right)^{2}$.
F. Significant difference between colonization and spore density for each variety at the different growth stages were carried out by ANOVA and seperated using Tukey using SPSS Statistics 20.

G. To examine the relationship between the relative abundance of AM fungi and the physicochemical properties of soil at the different ecosystems, Canonical correspondence analysis (CCA) was carried out using Multivariate Statistical Package (MVSP) program version 3.1.

\section{Results and Discussion}

\section{Soil Physicochemical Analyses}

Goa is one of the smallest states of India and accounts for about one percent of the total area of the country. It has a $101 \mathrm{~km}$ long coast line. Its length from north to south is $105 \mathrm{~km}$ and from west to east is $60 \mathrm{~km}$. It is part of the Konkan region which is an escarpment rising up to the Western Ghats. Most of Goa's soils is made up of laterite rock. Along the river banks, the soil is mostly alluvial and loamy. The soil is rich in minerals and humus and hence conducive to plantation. The results of the physicochemical analyses of the soil of the three ecosystems (Table 1) studied are depicted in Tables 2 and 3. The soils of the three ecosystems were acidic with its average $\mathrm{pH}$ ranging from 5.42 to 5.62. However, there was a significant difference in organic carbon $(\mathrm{OC})$, nitrogen $(\mathrm{N})$, manganese $(\mathrm{Mn})$ and potassium (K) (Table 4). OC, $\mathrm{N}$ and $\mathrm{Mn}$ were maximum in the uplands and the least in the midland. This variation in soil could be due to fertilizer application [25], vegetation, cropping history, temperature and type of ecosystem.

\section{AM Fungal Root Colonization}

AM fungal root colonization was recorded in all the three rice varieties for all the growth stages in both years in each rice growing ecosystem. In all the three varieties, the different ecosystems and growth stages had a significant effect on AM colonization for both years of study.

In all the three rice varieties (Fig. 1a-c) studied, i.e., Jyoti, Khonchri and Jaya, maximum colonization was observed in upland and midland during the flowering stage and minimum colonization in the lowlands at the vegetative stage for both years. It has been documented that flooding in the lowland and high-input cropping systems depresses AM fungal colonization in rice roots [22, 26]. The extent of root colonization is known to vary with soil and climatic conditions [33]. 
Table 2 Physicochemical properties of soil (2015)

\begin{tabular}{|c|c|c|c|c|c|c|c|c|c|c|}
\hline $\begin{array}{l}\text { Land type and } \\
\text { growth stage }\end{array}$ & $\mathrm{pH}$ & $\begin{array}{l}\mathrm{EC} \\
\left.(\mathrm{dS} \mathrm{m})^{-}\right)\end{array}$ & $\begin{array}{l}\text { Organic } \\
\text { carbon }(\%)\end{array}$ & $\begin{array}{l}\text { Nitrogen } \\
\left(\mathrm{kg} \mathrm{ha}^{-1}\right)\end{array}$ & $\begin{array}{l}\text { Phosphorus } \\
\left(\mathrm{kg} \mathrm{ha}^{-1}\right)\end{array}$ & $\begin{array}{l}\text { Potassium } \\
\left(\mathrm{kg} \mathrm{ha}^{-1}\right)\end{array}$ & $\begin{array}{l}\text { Iron } \\
(\mathrm{ppm})\end{array}$ & $\begin{array}{l}\text { Manganese } \\
(\mathrm{ppm})\end{array}$ & $\begin{array}{l}\text { Copper } \\
(\mathrm{ppm})\end{array}$ & $\begin{array}{l}\text { Zinc } \\
(\mathrm{ppm})\end{array}$ \\
\hline LV & 5.93 & 0.06 & 1.44 & 400.18 & 28.9 & 208.9 & 34.49 & 20.6 & 2.74 & 1.46 \\
\hline $\mathrm{LF}$ & 5.8 & 0.13 & 1.01 & 298.36 & 17.14 & 153.55 & 28.12 & 8.38 & 1.01 & 2.21 \\
\hline LH & 5.7 & 0.12 & 1.3 & 356.11 & 125.83 & 162.06 & 38.5 & 18.87 & 2.76 & 2.57 \\
\hline MV & 6.05 & 0.18 & 0.65 & 253.96 & 63.38 & 95.93 & 31.65 & 14.57 & 2.3 & 2.07 \\
\hline MF & 5.78 & 0.1 & 0.98 & 152.1 & 117 & 117.55 & 40.86 & 14.75 & 2.15 & 2.76 \\
\hline $\mathrm{MH}$ & 5.91 & 0.18 & 0.62 & 212.2 & 210.28 & 87.31 & 35.35 & 6.01 & 1.03 & 0.91 \\
\hline UV & 6.39 & 0.17 & 3.64 & 1115.93 & 85.17 & 205.19 & 38.32 & 23.27 & 1.69 & 1.12 \\
\hline UF & 5.95 & 0.06 & 4.53 & 1000.67 & 55.37 & 155.66 & 37.85 & 20.48 & 1.36 & 0.68 \\
\hline UH & 5.84 & 0.22 & 4.46 & 864.78 & 69.08 & 117.33 & 36.67 & 22.98 & 1.66 & 0.58 \\
\hline
\end{tabular}

Data presented is mean of six readings at each growth stage $L V$ lowland vegetative stage, $L F$ lowland flowering stage, $L H$ lowland harvesting, $M V$ midland vegetative stage, $M F$ midland flowering stage, $M H$ midland harvesting, $U V$ upland vegetative stage, $U F$ upland flowering stage, $U H$ upland harvesting

Table 3 Physicochemical properties of soil (2016)

\begin{tabular}{lllllllllrr}
\hline $\begin{array}{l}\text { Land type and } \\
\text { growth stage }\end{array}$ & $\mathrm{pH}$ & $\begin{array}{l}\mathrm{EC} \\
\left.(\mathrm{dS} \mathrm{m})^{-1}\right)\end{array}$ & $\begin{array}{l}\text { Organic } \\
\text { carbon }(\%)\end{array}$ & $\begin{array}{l}\text { Nitrogen } \\
\left(\mathrm{kg} \mathrm{ha}^{-1}\right)\end{array}$ & $\begin{array}{l}\text { Phosphorus } \\
\left(\mathrm{kg} \mathrm{ha}^{-1}\right)\end{array}$ & $\begin{array}{l}\text { Potassium } \\
\left(\mathrm{kg} \mathrm{ha}^{-1}\right)\end{array}$ & $\begin{array}{l}\text { Iron } \\
(\mathrm{ppm})\end{array}$ & $\begin{array}{l}\text { Manganese } \\
(\mathrm{ppm})\end{array}$ & $\begin{array}{l}\text { Copper } \\
(\mathrm{ppm})\end{array}$ & $\begin{array}{l}\text { Zinc } \\
(\mathrm{ppm})\end{array}$ \\
\hline LV & 4.34 & 0.29 & 1.22 & 245.77 & 34.27 & 200.31 & 50.36 & 5.71 & 0.29 & 1.57 \\
LF & 5.17 & 0.46 & 1.02 & 260.18 & 36.3 & 227.93 & 36.34 & 8.26 & 0.29 & 1.18 \\
LH & 5.55 & 0.68 & 1.76 & 210.63 & 39.23 & 380.7 & 26.66 & 14.3 & 0.33 & 0.86 \\
MV & 5.55 & 0.09 & 0.92 & 127.52 & 38.45 & 109.84 & 20.4 & 4.6 & 0.21 & 6.44 \\
MF & 5.07 & 0.21 & 1.59 & 294.44 & 31.76 & 95.62 & 19.04 & 7.62 & 0.08 & 0.45 \\
MH & 4.96 & 0.38 & 0.59 & 165.16 & 32.23 & 86.39 & 32.83 & 2.34 & 0.12 & 0.84 \\
UV & 5.62 & 0.09 & 1.6 & 499.74 & 20.36 & 252.52 & 37.76 & 17.71 & 0.16 & 0.81 \\
UF & 4.71 & 0.25 & 2.32 & 435.57 & 26.03 & 172.22 & 28.11 & 7.21 & 0.14 & 1.12 \\
UH & 5.19 & 0.08 & 2.59 & 369.56 & 40.04 & 76.84 & 39.97 & 13.73 & 0.21 & 0.51 \\
\hline
\end{tabular}

Data presented is mean of six readings at each growth stage; $L V$ lowland vegetative stage, $L F$ lowland flowering stage, $L H$ lowland harvesting, $M V$ midland vegetative stage, $M F$ midland flowering stage, $M H$ midland harvesting, $U V$ upland vegetative stage, $U F$ upland flowering stage, $U H$ upland harvesting

\section{AM Fungal Spore Density}

In the present study, average spore density in rhizosphere soil samples in various growth stages and different rice growing ecosystems was estimated. The present study revealed that phenology and sampling site had significant effect on spore density. AM fungal spore density increased at harvesting stage compared to the vegetative and flowering stage irrespective of rice variety and ecosystem (Fig. 2a-c). Similar results were observed by Janos [18] and Redhead [35]. According to Bentivenga and Hetrick [5], AM fungal sporulation is stimulated as the plant nutrient requirement reduces. The rise in AM spore population at harvest stage may be due to fungal resource mobilization from the senescing roots [10, 28, 47]. Compared to the midland and upland, the spore density was low in lowlands for both the years. This may be because of the anaerobic soil conditions caused due to flooding [30] and nutrients availability [2]. However, Miller and Beaver [27] identified two mechanisms by which AM fungi could survive in anoxic conditions. Firstly, some AM species may require less oxygen, and secondly, the AM fungus could be concentrated near the plant roots, obtaining oxygen directly from the root or as oxygen diffuses from the root into the rhizosphere.

The role of soil nutrient concentration on colonization ability by AM fungi and spore density was investigated during the study. There was no significant correlation between root colonization percentage and sporedensity. AM fungal colonization depends on soil moisture and $\mathrm{P}$ availability $[38,49,50]$ and physiological growth rate and turnover of plant root [21]. However, a significant correlation of spore density with nitrogen $(r=0.457)$, phosphorus $(r=0.504)$ and OC $(r=0.547)$ was observed at 
Table 4 Average physicochemical properties of soil

\begin{tabular}{|c|c|c|c|}
\hline \multirow[t]{2}{*}{ Physicochemical properties of soil } & \multicolumn{3}{|l|}{ Ecosystem } \\
\hline & Lowland & Midland & Upland \\
\hline $\mathrm{pH}$ & $5.41^{\mathrm{a}} \pm 0.24$ & $5.55^{\mathrm{a}} \pm 0.18$ & $5.61^{\mathrm{a}} \pm 0.24$ \\
\hline $\mathrm{EC}\left(\mathrm{dS} \mathrm{m} \mathrm{m}^{-1}\right)$ & $0.29^{\mathrm{a}} \pm 0.09$ & $0.19^{\mathrm{a}} \pm 0.04$ & $0.14^{\mathrm{a}} \pm 0.03$ \\
\hline Organic carbon $(\%)$ & $1.29^{\mathrm{b}} \pm 0.11$ & $0.89^{\mathrm{b}} \pm 0.15$ & $3.19^{\mathrm{a}} \pm 0.49$ \\
\hline Nitrogen $\left(\mathrm{kg} \mathrm{ha}^{-1}\right)$ & $295.05^{\mathrm{b}} \pm 29.49$ & $200.89^{b} \pm 26.29$ & $714.37^{\mathrm{a}} \pm 130.19$ \\
\hline Phosphorus $\left(\mathrm{kg} \mathrm{ha}^{-1}\right)$ & $46.94^{\mathrm{a}} \pm 16.09$ & $82.18^{\mathrm{a}} \pm 28.82$ & $49.34^{\mathrm{a}} \pm 10.29$ \\
\hline Potassium $\left(\mathrm{kg} \mathrm{ha}^{-1}\right)$ & $222.24^{\mathrm{a}} \pm 33.73$ & $98.77^{\mathrm{b}} \pm 5.09$ & $163.29^{\mathrm{ab}} \pm 25.45$ \\
\hline Iron (ppm) & $35.74^{\mathrm{a}} \pm 3.48$ & $30.02^{\mathrm{a}} \pm 3.50$ & $34.44^{\mathrm{a}} \pm 1.72$ \\
\hline Manganese (ppm) & $12.68^{\mathrm{ab}} \pm 2.51$ & $8.31^{\mathrm{b}} \pm 2.12$ & $17.56^{\mathrm{a}} \pm 2.53$ \\
\hline Copper (ppm) & $1.23^{\mathrm{a}} \pm 0.49$ & $0.98^{\mathrm{a}} \pm 0.41$ & $0.87^{\mathrm{a}} \pm 0.31$ \\
\hline Zinc (ppm) & $1.64^{\mathrm{a}} \pm 0.26$ & $2.24^{\mathrm{a}} \pm 0.91$ & $0.80^{\mathrm{a}} \pm 0.10$ \\
\hline
\end{tabular}

Data presented is mean of nine readings at each ecosystem, \pm indicates S.E.; for each ecosystem, values in the row affected by the same letter are not significantly different at $P \leq 0.05$ level of probability
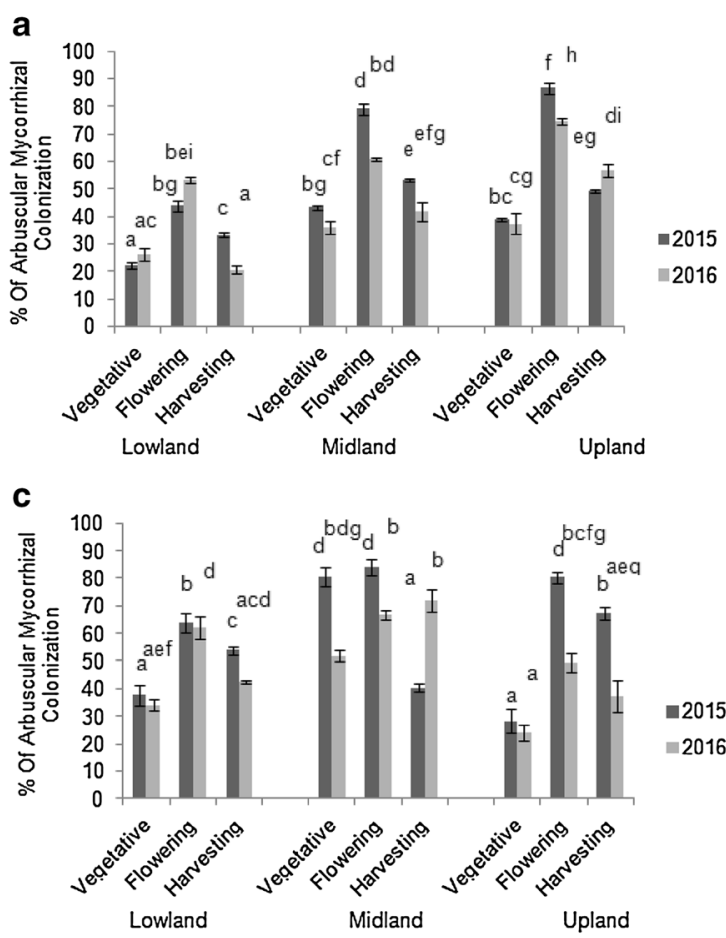

Fig. 1 Effect of plant phenology on AM fungal root colonization in $O$. sativa where a-var. Jyoti; b-var. Khonchri and c-var. Jaya. Data presented is the mean of three readings at each growth phase;

$P<0.05$ level. It is known that seasonality edaphic factors, age of host plant and dormancy can also contribute to variation in spore density [54].

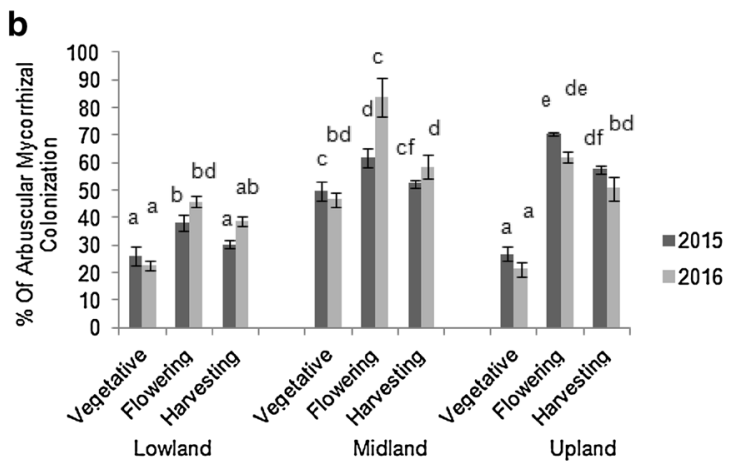

different letters within the variety of study indicate significant differences at $P \leq 0.05$; Bars represents SE

\section{AM Fungal Diversity, Richness, Abundance and Distribution}

A total of 17 AM fungal species belonging to six genera, viz., Acaulospora (9), Rhizoglomus (1), Entrophospora (1), Claroideoglomus (2) Funneliformis (1) and Gigaspora (3) with species number given in parenthesis were recorded from different ecosystems. The study revealed that 

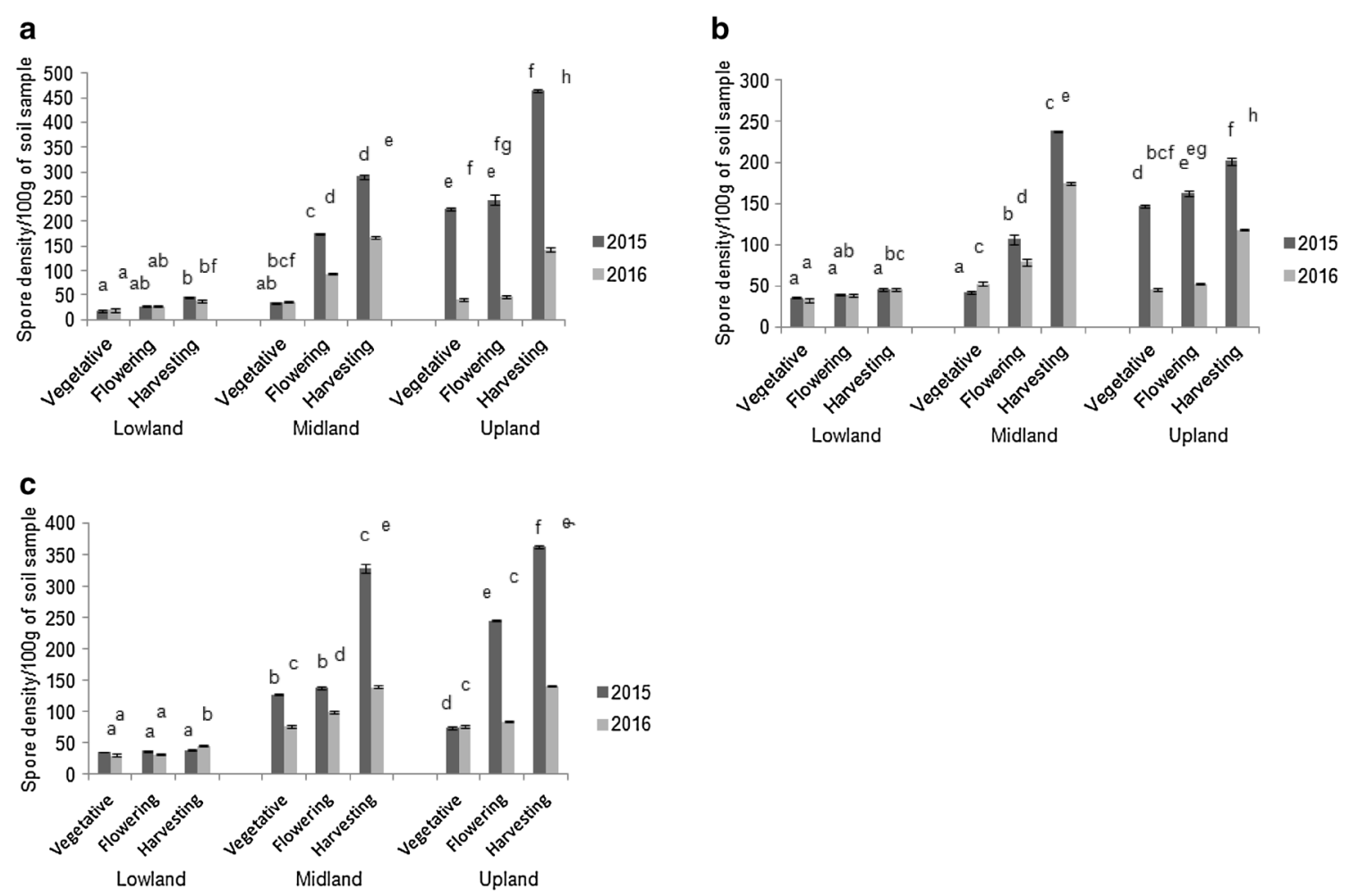

Fig. 2 Effect of Plant phenology on AM fungal spore density in $O$. sativa where a-var. Jyoti; b-var. Khonchri and c-var. Jaya. Data presented is the mean of three readings at each growth phase;

Acaulospora was the most dominant genus in the studied ecosystems. Maximum species richness was recorded in lowland (10) for both years with species number given in parenthesis.

In lowlands, Acaulospora scrobiculata, A. delicata, A. dilatata, A. laevis, A. tuberculata, A. myriocarpa, A. soloidea, Funneliformis mosseae, Rhizoglomus fasciculatum and Entrophospora nevadensis were recorded in both years. Frequency of occurrence was maximum for $A$. scrobiculata and $R$. fasciculatum as they were recorded in all the growth phases for both years (Table 5). Genus Acaulospora showed maximum relative abundance for both years (Fig. 3). Species of Acaulospora are identified mainly in low-input farming system, forest and grassland soils. They are considered as facultative symbionts adapted to a wide array of soils and host species, appearing in soils of widely different $\mathrm{pH}$ and nutrient availability $[39,43,46]$.

In midlands, Acaulospora scrobiculata, A. bireticulata, A. rehmii, A. dilatata Gigaspora ramisporophora, Claroideoglomus claroideum and Entrophospora nevadensis were recorded in 2015. In 2016, three additional species, viz., Funneliformis mosseae, Gigaspora albida and G. decipiens were recorded. Frequency of occurrence was maximum in A. scrobiculata and $G$. different letters within the variety of study indicate significant differences at $P \leq 0.05$; Bars represents S.E

ramisporophora (Table 6). Genus Gigaspora showed maximum relative abundance in both the years (Fig. 3). Similar observations were reported by Toppo et al. [48], suggesting Genus Gigaspora may be better adapted to semi-aerobic to anaerobic soils.

In the uplands, A. scrobiculata, A. bireticulata, Claroideoglomus claroideum, C. etunicatum and Entrophospora nevadensis were recorded in both years. Frequency of occurrence was maximum for $C$. claroideum (Table 7) and E. nevadensis. Genus Claroideoglomus showed maximum relative abundance for both years (Fig. 3). Predominance of Glomus in aerobic soil condition of uplands was observed by Maiti et al, [23] and Toppo et al, [48]. The dominance of Glomus in the uplands might be related to their competitive interaction and adaptability to aerobic conditions allowing them to establish better than others [41, 45].

The potential correlation of AM fungal abundance and physicochemical properties of the soil in the different ecosystems was performed by Canonical correspondence analysis (CCA). In the CCA plot, the length of the arrows illustrated the relative importance affecting the community, while the angle between the variables indicates the degree to which factors are correlated. The resulting ordination is presented in Fig. 4, and the Eigen values of the first and 
Table 5 Distribution of AM fungi at Lowlands

\begin{tabular}{|c|c|c|c|c|c|c|c|c|}
\hline \multirow[t]{2}{*}{ Sr. No. } & \multirow[t]{2}{*}{ AM species } & \multicolumn{3}{|l|}{2015} & \multicolumn{3}{|l|}{2016} & \multirow[t]{2}{*}{ Frequency of occurrence (\%) } \\
\hline & & Vegetative & Flowering & Harvesting & Vegetative & Flowering & Harvesting & \\
\hline 1 & Acaulospora scrobiculata & + & + & + & + & + & + & 100 \\
\hline 2 & Acaulospora delicata & - & + & + & - & + & + & 66.66 \\
\hline 3 & Acaulospora dilatata & - & - & + & - & - & + & 33.33 \\
\hline 4 & Acaulospora laevis & - & - & + & - & - & + & 33.33 \\
\hline 5 & Acaulospora tuberculata & - & - & + & - & - & + & 33.33 \\
\hline 6 & Acaulospora myriocarpa & + & - & + & + & - & - & 50.00 \\
\hline 7 & Acaulospora soloidea & - & + & + & - & - & + & 50.00 \\
\hline 8 & Funneliformis mosseae. & + & + & - & + & + & + & 83.33 \\
\hline 9 & Rhizoglomus fasciculatum & + & + & + & + & + & + & 100 \\
\hline 10 & Entrophospora nevadensis & - & + & + & - & + & + & 66.66 \\
\hline \multicolumn{2}{|c|}{ Species richness of AM fungi } & 4 & 6 & 9 & 4 & 5 & 9 & - \\
\hline
\end{tabular}

+ Presence of AM fungi; - absence of AM fungi

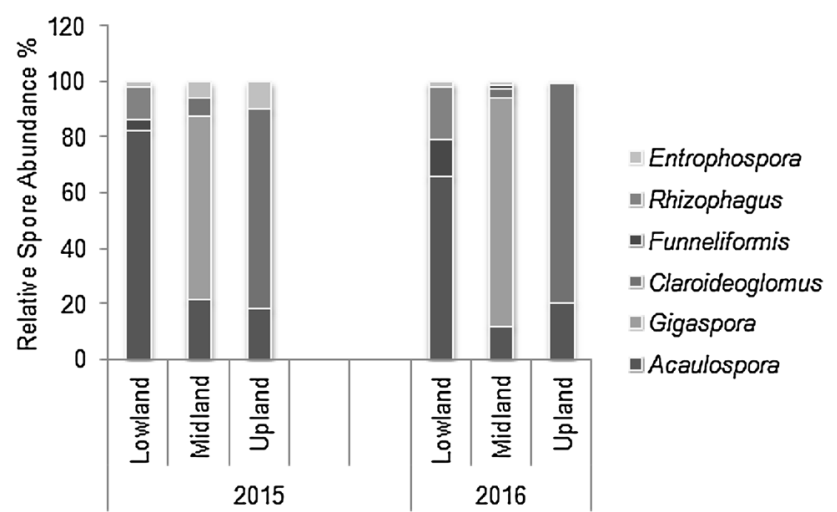

Fig. 3 Genus-wise relative abundance distribution of AM genera cultivated in different ecological sites for the year 2015 and 2016 second axes were 0.583 and 0.471 , respectively. The cumulative percentage variance of genera data showed $34.83 \%$ and $62.95 \%$ of variability on the first and second axes, respectively. Genus Claroideoglomus shows a high relative abundance $\%$ in the uplands which is closely related to the high content of $\mathrm{OC}, \mathrm{N}, \mathrm{Mn}$ and Fe content in the soil. Midlands show a high relative abundance $\%$ of the genus Gigaspora, and it is strongly related to the high content of $\mathrm{Zn}$ and low content of P. In the lowlands, the genus Acaulospora shows a high relative abundance percentage which shows tolerance to EC fluctuations, $\mathrm{Cu}$ and $\mathrm{K}$ content.

Diversity was calculated by using Shannon's diversity index $(\mathrm{H})$ and Simpson's index of diversity (D) at the

Table 6 Distribution of AM fungi at midlands

\begin{tabular}{|c|c|c|c|c|c|c|c|c|}
\hline \multirow[t]{2}{*}{ Sr. No. } & \multirow[t]{2}{*}{ AM species } & \multicolumn{3}{|l|}{2015} & \multicolumn{3}{|l|}{2016} & \multirow[t]{2}{*}{ Frequency of occurrence $(\%)$} \\
\hline & & Vegetative & Flowering & Harvesting & Vegetative & Flowering & Harvesting & \\
\hline 1 & Acaulospora scrobiculata & + & + & + & + & + & + & 100 \\
\hline 2 & Acaulospora bireticulata & - & - & + & - & - & + & 33.33 \\
\hline 3 & Acaulospora dilatata & + & - & - & - & - & - & 16.66 \\
\hline 4 & Acaulospora rehmii & + & - & + & + & - & + & 66.66 \\
\hline 5 & Gigaspora ramisporophora & + & + & + & + & + & + & 100 \\
\hline 6 & Gigaspora albida & - & - & - & - & + & + & 33.33 \\
\hline 7 & Gigaspora decipiens & - & - & - & - & + & + & 33.33 \\
\hline 8 & Claroideoglomus claroideum & - & - & + & - & - & + & 33.33 \\
\hline 9 & Funneliformis mosseae. & - & - & - & + & - & - & 16.66 \\
\hline 10 & Entrophospora nevadensis & - & + & + & - & + & + & 66.66 \\
\hline \multicolumn{2}{|c|}{ Species richness of AM fungi } & 4 & 3 & 6 & 4 & 5 & 8 & - \\
\hline
\end{tabular}

+ Presence of AM fungi; - absence of AM fungi 
Table 7 Distribution of AM fungi at uplands

\begin{tabular}{|c|c|c|c|c|c|c|c|c|}
\hline \multirow[t]{2}{*}{ Sr. No. } & \multirow[t]{2}{*}{ AM species } & \multicolumn{3}{|l|}{2015} & \multicolumn{3}{|l|}{2016} & \multirow[t]{2}{*}{ Frequency of occurrence $\%$} \\
\hline & & Vegetative & Flowering & Harvesting & Vegetative & Flowering & Harvesting & \\
\hline 1 & Acaulospora scrobiculata & + & + & - & + & + & - & 66.66 \\
\hline 2 & Acaulospora bireticulata & - & - & + & - & - & + & 33.33 \\
\hline 3 & Claroideoglomus claroideum & + & + & + & + & + & + & 100 \\
\hline 4 & Claroideoglomus etunicatum & - & + & + & - & + & + & 66.66 \\
\hline 5 & Entrophospora nevadensis & + & + & + & + & + & + & 100 \\
\hline \multicolumn{2}{|c|}{ Species Richness of AM Fungi } & 3 & 4 & 4 & 3 & 4 & 4 & - \\
\hline
\end{tabular}

+ Presence of AM fungi; - absence of AM fungi

\section{CCA joint plot}

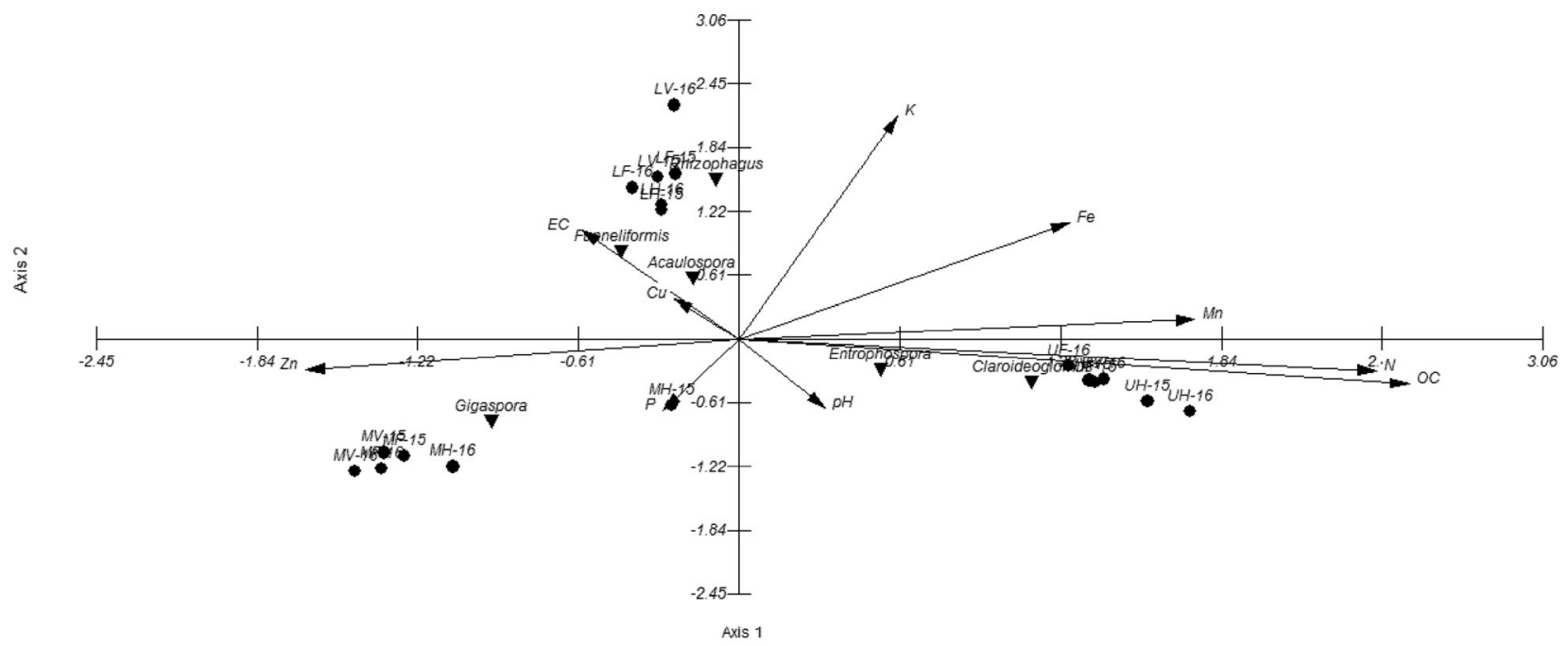

Vector scalina: 2.97

Fig. 4 CCA of soil physicochemical properties and relative spore abundance $\%$ of different AM genera in different ecosystems. Diagram of CCA of soil properties pH, EC, OC, N, P, K, S, Fe, $\mathrm{Mn}, \mathrm{Cu}, \mathrm{Zn}$ and Genus-wise relative abundance distribution of AM genera at the different ecosystems: $L V$ Lowland vegetative stage, $L F$ lowland flowering stage, $L H$ lowland harvesting, $M V$ midland vegetative stage, $M F$ midland flowering stage, $M H$ midland harvesting, $U V$ upland vegetative stage, $U F$ upland flowering stage, $U H$ upland harvesting
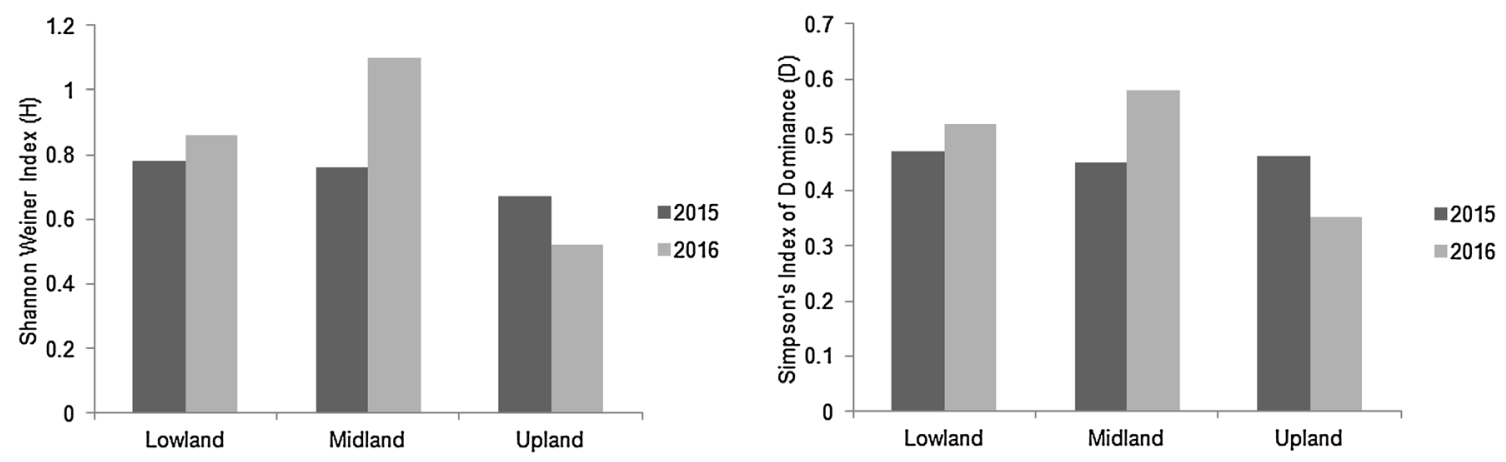

Fig. 5 AM fungal species density in $O$. sativa. Data presented is the mean of nine readings at each ecosystem 
species level for the three ecosystems (Fig. 5). Maximum AM diversity was recorded in lowlands in 2015, midland in 2016 and minimum in uplands for both the years. Some AM fungi have high tolerance to soil hypoxia or even anoxia [51]. High diversity may be important for buffering an ecosystem against disturbances [49]. Occurrence of maximum number of species results in higher index of diversity. Maximum diversity observed in the lowlands indicated shared dominance of many AM fungal genera. The lowest diversity observed in uplands indicates dominance of a few genera.

\section{Conclusions}

All the rice fields in the different ecosystems are conventionally managed with each ecosystem having its own cultivation practice. The difference in ecosystem, ecology and cultural practices can cause changes in the suitability for growth of AM fungi. Hence, AM fungi tolerant to conditions in a particular ecosystem proliferate. In the present study, dominance of different genera in different ecosystems, viz, genus Acaulospora dominant in lowlands, Gigaspora in midlands and Claroideoglomus in uplands was observed. As AM fungal colonization from the native soil is better in efficacy [31], cost effectiveness and adaptation with lesser negative ecological consequences in terms of invasive species [37], they can be employed as inocula for different ecosystems. Our study suggests the suitability of Acaulospora inocula in lowland (khazans), Gigaspora in midland (ker) and Claroideoglomus in Upland (morod) fields.

Open Access This article is distributed under the terms of the Creative Commons Attribution 4.0 International License ( http://creativecommons.org/licenses/by/4.0/), which permits unrestricted use, distribution, and reproduction in any medium, provided you give appropriate credit to the original author(s) and the source, provide a link to the Creative Commons license, and indicate if changes were made.

\section{References}

1. Almeida RT, Schenck NC (1990) A revision of the genus Sclerocystis (Glomaceae, Glomales). Mycologia 82:703-714

2. Augé RM (2001) Water relation, drought and VA mycorrhizal symbiosis. Mycorrhiza 11:3-42

3. Barea JM (1991) Vesicular-arbuscular mycorrhizae as modifiers of soil fertility. In: Stewart BS (ed) Advances in soil science, vol 15. Springer, New York

4. Beena KR, Raviraja NS, Arun AB, Sridhar KR (2000) Diversity of arbuscular mycorrhizal fungi on the coastal sand dunes of the West Coast of India. Curr Sci 79(10):1459-1465

5. Bentivenga SP, Hetrick BAD (1992) Seasonal and temperature effect on mycorrhizal activity and dependence of cool and warmseason tall grass prairie grasses. Can J Bot 70(8):1596-1602
6. Bray RH, Kurtz LT (1945) Determination of total organic and available forms of phosphorus in soils. Soil Sci 59:39-45

7. Gerdemann JW, Nicolson TH (1963) Spores of mycorrhizal Endogone species extracted from soil by wet sieving and decanting. Trans Br Mycol Soc 46:235-244

8. Gianinazzi S, Vosatka M (2004) Inoculum of arbuscular mycorrhizal fungi for production system, science meets business. Can J Bot 82(8):1264-1271

9. Hanway JJ, Heidel H (1952) Soil analysis method as used in Iowa State College soil testing laboratory. Iowa State Coll Agric $57: 1-31$

10. Hayman DS (1970) Endogone spore numbers in soil and VAM in wheat as influenced by seasons and soil treatment. Trans $\mathrm{Br}$ Mycol Soc 54:53-63

11. Herdt RW, Palacpac AC (1983) World rice facts and trends. In: International Rice Research Institute, PO Box 933, Manila, Philippines, 41p

12. Huke RE (1982) Rice area by type of culture: south and southeast Asia. In: International Rice Research Institute, PO Box 933, Manila, Philippines, 32p

13. Ilag LL, Rosales AM, Elaegvi FV, Mew TW (1987) Changes in the population of infective endomycorrhizal fungi in a rice based cropping system. Plant Soil 103:67-73

14. Ipsilantis I, Sylvia DM (2007) Interaction of assemblages of mycorrhizal fungi with two Florida wetland plants. Appl Soil Ecol 35:261-271

15. IRRI (International Rice Research Institute) (1997) Rice almanac, 2nd edn. International Rice Research Institute, Los Banaos Philippines

16. Ito O, Ella E, Kawano N (1999) Physiological basis of submergence tolerance in rainfed lowland rice ecosystem. Field Crops Res 64:75-90

17. Jackson ML (1973) Soil chemical analysis. Prentice Hall of India Pvt. Ltd., New Delhi, pp 1-485

18. Janos DP (1980) Mycorrhizal tropical succession. Biotropica 12(suppl):56-95

19. Justin SHFW, Armstrong W (1987) The anatomical characteristics of roots and plant response to soil flooding. New Phytol 106:465-495

20. Lindsay WL, Norwell WA (1978) Development of DTPA soil test for zinc, iron, manganese and copper. Soil Sci Soc Am J 42:421-428

21. Lugo M, Gonzalez ME, Cabello MN (2003) Arbuscular mycorrhizal fungi in a mountain grassland, seasonal variation of colonization studied, along with its relation to grazing and metabolic host type. Mycologia 95:407-415

22. Lumini E, Vallino M, Alguacil MM, Romani M, Bianciotto V (2010) Different farming and water regimes in Italian rice fields affect arbuscular mycorrhizal fungal soil communities. Ecol Appl 21(5):1696-1757

23. Maiti D, Variar M, Saha J (1995) Colonization of upland rice by native VAM under direct mono- cropped ecosystem. In: Roy AK, Sinha KK (eds) Recent advances in phytopathological research. MD Publ. Ltd, New Delhi

24. Manjunath BL, Prabhu Desai HR, Ramesh R, Manohar KK, Singh NP (2011) Improved production technology for rice in Goa. In: Technical bulletin no. 24. ICAR Research Complex for Goa. Old Goa-403402. Goa India

25. Mathimaran N, Ruh R, Jama B, Verchot L, Frossard E, Jansa J (2007) Impact of agricultural management on arbuscular mycorrhizal fungal communities in Kenyan ferralsol. Agric Ecosyst Environ 119:22-32

26. Miller S (2000) Arbuscular mycorrhizal colonization of semi aquatic grasses along a wide hydrological gradient. New Physiol $145: 145-155$ 
27. Miller SP, Bever JD (1999) Distribution of arbuscular mycorrhizal fungi in stands of the wetland grass Punicum hemitomon along a wide hydrologic gradient. Oecologia 119:586-592

28. Muthukumar T, Sha LQ, Yang XD, Cao M, Tang JW, Zheng Z (2003) Mycorrhiza of plants in different vegetation types in tropical ecosystem of Xishuangbanna, southwest China. Mycorrhiza 13:289-297

29. Nielsen KB, Kjoller R, Olsson PA, Schweiger PF, Andersen FO, Rosendahl S (2004) Colonization and molecular diversity of arbuscular mycorrhizal fungi in the aquatic plants Littorella uniflora and Lobelia dortmanna in southern Sweden. Mycol Res 108:616-625

30. Nopamornbodi O, Thumsurakul S, Vasuvat Y (1987) Survival of VA mycorrhizal fungi after paddy rice. In: Sylvia DM, Hung LL, Graham JH (eds) Mycorrhizae in the next decade. Practical applications and research priorities. Institute of Food and Agriculture Science University of Florida, Gainesville, pp 53-58

31. Oliveira RS, Vosatka M, Dodd JC, Castro PML (2005) Studies on the diversity of arbuscular mycorrhizal fungi and the efficacy of two native isolates in highly alkaline anthropogenic sediment. Mycorrhiza 16:23-31

32. Phillip JM, Hayman DS (1970) Improved procedure for clearing root and staining parasite and vesicular arbuscular mycorrhizal fungi for rapid assessment of infections. Trans Br Mycol Soc 55:158-160

33. Rajan SK, Reddy BJD, Bagyaraj DJ (2000) Screening of arbuscular mycorrhizal fungi for their symbiotic efficiency with Tectona grandis. Forest Ecol Manag 126:91-95

34. Read DJ, Koucheki HK, Hodgson J (1976) Vesicular-arbuscular mycorrhiza in natural vegetation systems. 1. The occurrence of infection. New Phytol 77:641-653

35. Redhead JF (1977) Endotrophic mycorrhizas in Nigeria: species of endogonaceae and their distribution. Trans $\mathrm{Br}$ Mycol Soc 69:275-280

36. Rodrigues BF, Muthkumar T (2009) Arbuscular mycorrhizae of Goa-a manual of identification protocols. Goa University, Goa

37. Schenck NC, Perez Y (1990) Manual for the identification of VA mycorrhizal fungi. In: International culture collection of VA mycorrhizal fungi. Synergistic Publication, Gainesville

38. Selvaraj T, Chellappan P, Jeong YJ, Kim H (2004) Occurrence of vesicular arbuscular mycorrhizal (VAM) fungi and their effect on plant growth in endangered vegetation. J Microbiol Biotechnol $14: 885-890$

39. Sieverding E (1991) Vesicular-arbuscular mycorrhizal management in tropical agro system. German Technical Co- operation (GZT), Eschborn

40. Simpson EH (1949) Measurement of diversity. Nature 163(4148):688
41. Singh S, Pandey A, Chaurasia B, Palni LMS (2008) Diversity of arbuscular mycorrhizal fungi associated with the rhizosphere of tea growing in natural and cultivated ecosites. Biol Fertil Soils 44:491-500

42. Shannon CE, Weaver W (1949) The mathematical theory of communication. University of Illinois, Urban

43. Shepherd KD, Jefwa J, Wilson J, Ndufa JK, Ingleby K, Mbuthu KW (1996) Infection potential of farm soils as mycorrhizal inncula for Leucaena leucocephala. Biol Fertil Soils 22:16-21

44. Solaiman ZM, Hirata H (1998) Glomus-wetland rice mycorrhizas influenced by nursery inoculation techniques under high fertility soil conditions. Biol Fert Soils 27:92-96

45. Songachan LS, Kayang H (2011) Diversity of arbuscular mycorrhizal fungi in pine forest of Meghalaya, North East India. Mycosphere 2(4):497-505

46. Straker CJ, Hilditch AJ, Rey MEC (2010) Arbuscular mycorrhizal fungi associated with cassava (Manihot esculenta Crantz). S Afr J Bot 76:102-111

47. Sutton JC, Barren GL (1972) Population dynamics of Endogone spores in soil. Can J Bot 50:1909-1914

48. Toppo NN, Maiti D, Srivastava AK (2012) Native arbuscular mycorrhizal fungal diversity in rice- based cropping system under rainfed ecosystem. Columban J Life Sci 13(1\&2):79-85

49. Vogt K, Asbjornsen H, Ercelawn A, Montagnini F, Valdes M (1997) Roots and mycorrhizae in plantation ecosystem. In: Nambiar EKS, Brown AG (eds) Management of soil, nutrients and water in tropical plantation forests. ACIAR, Canberra, pp 247-296

50. Wang YT, Qui Q, Yang ZY, Hu ZJ, Fung-Yee Tam N, Xin GR (2010) Arbuscular mycorrhizal fungi in two mangroves in South China. Plant Soil 33:181-191

51. Wang Y, Huang Y, Qiu Q, Xin G, Yang Z, Shi S (2011) Flooding greatly affects the diversity of arbuscular mycorrhizal fungi communities in the roots of wetland plants. PLoS ONE 6:e24512

52. Walkey A, Black JA (1934) An examination of the Degtjareff method for determining soil organic matter and a proposed modification of the chromic titration method. Soil Sci 37:29-38

53. Wirsel SGR (2004) Homogeneous stand of a wetland grass harbour diverse consortia of arbuscular mycorrhizal fungi. FEMS Microbiol Ecol 48:129-138

54. Zhao ZW (1999) Population composition and seasonal variation of VA mycorrhizal fungi spores in the rhizosphere of four pteridophytes. ABY 21:437-441

Publisher's Note Springer Nature remains neutral with regard to jurisdictional claims in published maps and institutional affiliations. 